\title{
$\left.\sum 4\right]$ \\ Evaluation of Tarannum Al-Quran Teaching in Malaysian National Religious Secondary School
}

\author{
*Farah Ilyani binti Zakaria ${ }^{1}$, Mohd Aderi Che Noh ${ }^{2}$, Khadijah Abdul Razak ${ }^{3}$, Hafizhah Zulkifli ${ }^{4}$ \\ ${ }^{1,3,4}$ Universiti Kebangsaan Malaysia, 43600 UKM, 43600 Bangi, Malaysia \\ ${ }^{2}$ Universiti Sains Islam Malaysia, Bandar Baru Nilai, 71800 Nilai, Negeri Sembilan, Malaysia \\ *zfarahilyani@yahoo.com
}

\begin{abstract}
This study aims to examine students' perceptions of the implementation of Tarannum al-Quran teaching in Program Kelas Khas Kemahiran al-Quran (KKQ) from the aspect of the teaching development process in the classroom based on the CIPP Model (Stufflebeam \& Shinkfield 1985). Data were obtained through questionnaires and semistructured interviews. The sample of this study involved 78 from four $K K Q$ students in religious, national secondary schools (SMKA), including boarding schools (SBP) in the state of Selangor from 106 population and three teachers as participants. The validity and reliability of the questionnaire instrument obtain a high value with a correlation score between items exceeding 0.25 in addition to content verification by expert reference panel and an overall alpha value of 0.95. At the same time, the semi-structured interview protocol was also confirmed by experts. Questionnaire data were analyzed descriptively using Statistical Package for Social Sciences (SPSS) 11.5 involving frequency, percentage, mean and standard deviation. At the same time, the interview data were analyzed and transcribed verbatim to identify the elements involved. The findings show that teachers understand and implement the necessary details in the teaching development process, but it is only moderately high. These elements can be seen through various techniques and strategies, taking into account the diversity of students' levels and abilities and the positive reinforcement that always occurs in the interaction of teachers and students. In conclusion, the implementation of teaching at the stage of teaching development is only at a moderately high level with incremental implications that require continuous development and improvement.
\end{abstract}

Kajian ini bertujuan untuk meninjau persepsi murid terhadap pelaksanaan pengajaran Tarannum al-Quran Program Kelas Khas Kemahiran al-Quran (KKQ) dari aspek proses perkembangan pengajaran di dalam kelas berasaskan Model CIPP (Stufflebeam \& Shinkfield 1985). Data diperoleh melalui soal selidik dan temu bual separa berstruktur. Sampel kajian ini melibatkan 78 orang murid tingkatan empat KKQ di sekolah-sekolah menengah kebangsaan agama (SMKA) termasuk sekolah-sekolah berasrama penuh (SBP) di negeri Selangor daripada 106 bilangan populasi dan 3 peserta kajian guru. Kesahan dan kebolehpercayaan instrumen soal selidik mempunyai nilai yang tinggi dengan skor kolerasi di antara item melebihi 0.25 di samping pengesahan kandungan oleh panel rujukan pakar dan nilai alpha keseluruhan 0.95. Manakala protokol temu bual separa berstruktur turut disahkan oleh pakar. Data soal selidik dianalisis secara 
deskriptif menggunakan Statistical Package for Social Sciences (SPSS) 11.5 yang melibatkan kekerapan, peratus, min dan sisihan piawai. Manakala data temu bual dianalisis dan ditranskripkan secara verbatim bagi mengenalpasti elemen-elemen terlibat. Dapatan kajian menunjukkan guru memahami dan melaksanakan elemen-elemen yang perlu ada di dalam proses perkembangan pengajaran namun ia hanya berada pada tahap sederhana tinggi. Elemen-elemen tersebut dapat dilihat melalui penggunaan teknik dan strategi yang pelbagai dengan mengambil kira kepelbagaian tahap dan kebolehan murid di samping peneguhan positif yang sentiasa berlaku dalam interaksi guru dan murid. Kesimpulannya, pelaksanaan pengajaran guru pada peringkat perkembangan pengajaran hanya berada pada tahap sederhana tinggi dengan implikasi inkremental yang memerlukan pembangunan dan penambahbaikan yang berterusan.

\section{Keywords: Tarannum al-Quran, Teaching Evaluation, Teaching Development.}

Received: February 09, 2021; Revised: April 23, 2021; Accepted: May 01, 2021

\section{INTRODUCTION}

The Al-Quran Reading and Memorization Skills Special Class Program (KKQ) is one of the exclusive al-Quran education programs under the MOE, which has been established since 1986 (Yusof, 2004b). The subjects studied are al-Quran subjects that require more skills. High compared to the recitation syllabus in the subjects of Tilawah al-Quran, namely Tarannum, Qiraat as-Sab'ie, Tajwid, Ulum al-Quran and Hafazan (JAPIM, 2004). Students who take this class consist of students eligible to follow KKQ at SMKA, SMK KAA, SBP, SBPI, SAM and Special Model Schools throughout the country (Hasan, 2008). But until now, studies that touch on the teaching and learning of Tarannum al-Quran Special Class of al-Quran Skills began to get the attention of researchers when the reality showed less encouraging achievements in that aspect than other skills subjects (Jaid, 2008).

Thus, this article highlights a program evaluation study using the CIPP Evaluation Model (Stufflebeam and Shinkfield, 1985), which was conducted to evaluate the implementation of teaching and learning Tarannum al-Quran Special Class Program for Reading and Memorizing al-Quran (KKQ) in SMKA through components context, input, process and product. However, this article only explains one of the aspects of the process component, namely the development of teaching as a study of the article, without discussing the opening and closing aspects of teaching and the use of ABM (Mat, 2010).

\section{Teacher Teaching Effectiveness}

Teachers play an essential role in producing effective teaching. According to Abd, effective teaching occurs through appropriate teaching skills, techniques, and methods in each teaching session. Ghafar, education refers to how a teacher conveys lessons or knowledge to his students (Din, 2003).

The same is true in the teaching of the Qur'an, which is associated with the lack of creativity of teachers who convey the knowledge of the Qur'an in diversifying the way of explanation and use of teaching aids (Purwanto, 1990); (Jemali, 2006); (Noh and 
Tarmizi, 2009). Moreover, the teaching of Tarannum al-Quran also requires specific knowledge of teaching methods by Al-Syaibani, who stated that teaching methods must be different depending on the purpose of education (Al-Syaibani, 1978). Thus, the teacher must choose the appropriate method for a subject taught so that the learning process will be more effective. According to al-Kailany and Mulhim, the methods used while conducting the Quran should match the teaching objectives (AlKailany and Iyad, 1986). Thus al-Kailany and Mulhim outline five things as a guide to teachers in the selection of teaching methods of the Qur'an that is the method chosen must be by the purpose and objectives of teaching, by the nature of the subjects taught, appropriate or equivalent to the age of students and teachers must be able to use or apply the chosen method as well as sufficient time when applying any method (Myers and Myers, 1995). In this case, Kamarudin also lists several things that need to be considered, namely the suitability of methods and techniques used with the content taught, the suitability of teaching content measures, and the effectiveness of learning activities the concept and scope of the teaching are delivered (Husin, 1987). Straightforward and easy to understand, do teachers teach using textbooks entirely, is what is presented part of what is provided, how does the rate of communication from step to step and as students do work or experiments do teachers review their work.

Through this component of teaching development, teachers' ability to involve students should occur to avoid P\&P that occurs only teacher-centered. Thus, Kamarudin lists several things that need to be seen to ensure maximum student involvement (Husin, 1987). Among them are whether the students just sit and listen? The extent to which they are involved in learning activities; reading, writing, experimenting, making reports and so on ? is their involvement organized and purposeful ? is the involvement of students with their efforts or with the efforts of teachers? And who is the focus and so on? According to Myers and Myers, effective teachers need to involve students with academic learning (Myers and Myers, 1995). The activities and content of the subjects should be appropriate to the level of student learning so that they experience continuous improvement in achievement. This is in line with Brophy and Good (Brophy and Good, 1986). They reported that excellent teaching allows many students to continuously improve their achievement, high levels of achievement, little confusion and without losing momentum from one step to another.

According to Myers \& Myers as well, the findings of the study show the following about active teaching strategies, namely (Myers and Myers, 1995), (1) Concise presentation, involving question and answer, reading and feedback on students' ideas, (2) Presentation that is structured and arranged in a simple form so that students can follow it, (3) Make writing activities as an active experience for students and teachers. Teachers provide explanations, demonstrate models for assignments, lead, surround students and supervise work, check selections individually, provide feedback from time to time and encourage students to continue studies, (4) Use a variety of questions appropriate to teaching objectives, level of mastery, the concept of lesson content and intellectual abilities of students, (5) Successfully make new lesson connections with students' past knowledge and experience and allow students to recall the lesson for a period the old (Daughtery and Ristau, 1991), (6) Teachers check student comprehension.

Meanwhile, Mueller and Mueller stated that teachers who use limited teaching strategies would limit their abilities, which closes the space for all students (Mueller and Mueller, 1992). The proposal to diversify this method is also supported by Ruslin, 
who said that learning outcomes would increase if the teaching is carried out in a planned manner by considering the diversity of students and student levels (Amir, 2007). Ellis lists several effective teaching strategies. Among them are teachers using various teaching approaches that often create different class routines. Teachers engage with students through knowing the personal background of students, and students are actively involved in learning activities. Ellis also suggested that a teaching approach can create frequent positive interactions among students where high-achieving students can help their low-achieving peers (Ellis, 1995).

The opinion of Ellis is supported by Hazri Jamil, who put forward the view of Nichol (1984), who stated that teaching is a science and the process of teaching and learning is an experiment (Ellis, 1995);(Jamil, 2003). Thus, good and effective teaching depends on strategy, commitment, careful planning, and the use of various skills possessed by a teacher. According to Kamaruddin, exciting and meaningful activities are essential in teaching and learning (Husin, 1987). This will be able to attract students to focus on the teacher's teaching. Among the things that teachers need to do is always be active and fresh in their teaching, complete with appropriate and diverse teaching aids (Ikhwan et al., 2021).

Based on a study made by Shahril @ Charil (1998), the characteristics of quality teaching have features such as planned, structured and systematic instruction, emphasizing the critical content and accuracy of the content, relating the content to existing knowledge and experience of students, using a variety of teaching aids, using simple language, teaching using a variety of methods, conducting the continuous assessment, there is an element of obsession in teaching and using clear examples. In this regard, Ibn Khaldun explained that imparting knowledge in the teaching process should be gradual or gradual (Khaldun, 2000). This is because continuous teaching without taking into account students' ability will cause students to get bored and therefore not pay attention to the subjects taught. The role of this teacher is presented by Sulaiman, who argues that a teacher needs to understand some of the situations of his students to ensure the effectiveness of the teaching and learning process (Razali, 2001). Among them is that students pay attention if a teaching method is allowed to happen for too long, and students lose focus if there are no activities for them to do.

Abdullah has studied several aspects of history teaching, namely teacher preparation, goals and attitudes of teachers. The study found that teachers' attitude factors play a role in influencing teachers in the teaching process. This is because friendly interaction and positive reinforcement in teaching can arouse students' interest in studying (Abdullah, 2000). Thus, the role of teachers during the teaching development element also plays a position to ensure that students remain motivated and interested. Abdullah's findings are in line with the study of Ariffin, who stated that students prefer techniques that fit the objectives, clear teacher descriptions, discussion classes held in addition to the friendliness and friendliness of teachers (Ariffin, 1998).

A study conducted by Mohamad Sultan Faujdar found that the quality of History teaching in the study schools was considered poor quality when recording bad mean scores on the elements of relating the content to the existing knowledge and experience of students, using various teaching aids, conducting assessments continuously and use clear examples in teaching (Faujdar, 2000). At the same time, David G. Armstrong et al, said that a teacher should find what factors can motivate students and relate them to identifying the content of teaching (Armstrong, T.Henson 
and Savage, 2001). According to David et al, again, there are three levels of motivating students, namely; (i) Motivate students at the beginning of the lesson that is to introduce new things and relate them to students, (ii) Motivate students during the lesson that is to ensure the classroom environment is favourable, free from feelings of threat and fear and teachers should give full support to students, (iii) Motivating students at the end of the lesson is to inform students about the level of success they understand the knowledge of the day and how the lessons in the following days can improve their level of knowledge (Armstrong, T.Henson and Savage, 2001).

According to Woolfolk, guiding students towards academic interest can be achieved if teachers can make teaching and learning engaging in the classroom. Teachers can diversify teaching styles with various learning methods, use interactive teaching strategies and student engagement, incorporate humour or humour in teaching, be enthusiastic and creative in delivering lessons (Woolfolk, 2002). Teachers need to be aware of every need and type of their students, whether weak, average or intelligent. In addition, teachers should avoid the presentation of knowledge that is teachercentred or classroom-centred alone. Teachers need to excel and master understanding according to their respective areas of expertise (Noordin and Dan, 2002).

According to Sulaiman Razali, the teacher's ability to teach and easily understand students depends on the teacher's ability to organize and develop the content of the lesson (Razali, 2001). Teachers need to adapt their teaching according to the situation and time. Moreover, actively involve students in teaching and learning activities. Bruner once stated this (1966), if education is not balanced with students' existing abilities, perhaps learning will not achieve the expected objectives. Instead, what happens is that the student will experience a psychological barrier between himself and the teacher and the subject of History. Bruner (1966) stressed that effective teaching must evolve in line with the development of learning that is from direct experience (enactive) to representational experience (iconic) and then more abstract (symbolic) learning.

In this component of teaching development, teachers should observe the level of intellectual ability, whether excellent, average or weak. This is because Ibn Khaldun emphasizes that teachers need to know and understand the students' instincts, talents, and character (Khaldun, 2000). In addition, the effectiveness of the teaching development component also depends a lot on the compatibility between the methods, techniques or approaches of R \& D with the objectives to be achieved. This needs to be emphasized by teachers so that there is coordination between the lesson's contents with the approach, methods and teaching techniques used.

Meanwhile, Mok Soon Sang presented the skill of enlightenment as an essential skill in the development process of a lesson. Among the principles found in illuminating skills in the process of teaching, development is (Sang, 2009); (1) Teachers should plan to teach activities by choosing the appropriate way and form of explanation, (2) Examples, illustrations and teaching resources should be determined and prepared in advance, (3) Time to use illuminating skills should be short. Pupils will feel bored if asked to be silent to listen to the teacher's explanation for a long time, (4) To maintain pupils' interest in the explanation, stimulus variation skills should be used, especially for explanations longer than one minute, (5) Words and terms used to explain should be based on the student's level of ability and experience, (6) Description should be based on the student's past knowledge so that they can follow it quickly and 
meaningfully. The researcher has identified the appropriate elements to be examined and studied based on the literature review above.

The objective of this study was to evaluate the implementation of Tarannum al-Quran KKQ P\&P in process evaluation by focusing on the development component of teacher teaching from the perspective of students based on the CIPP Model (Stufflebeam and Shinkfield, 1985).

\section{METHOD}

This study combines quantitative and qualitative forms of research aimed at covering the strengths and weaknesses of each other. Thus, the overall picture through quantitative data findings can be seen more clearly and in-depth through qualitative data. Neuman stated that the best study is a study that often combines the features found in quantitative and qualitative studies because the strengths and weaknesses found in both forms of meditation will complement each other (Neuman, 2000). While Green and Mc Lintock once pointed out that the combination of various methods in one study will lead to a more accurate decision about the phenomenon studied (Green, J. \& Mc Lintock, 1985).

Thus, a set of questionnaires containing 24 items was used to obtain quantitative data on the evaluation of teacher teaching development from the perspective of students. At the same time, a semi-structured interview instrument was used to obtain qualitative data as support.

This study involved 78 students of KKQ from four programs, which covers almost the entire population of form four students in SMKA and SBP in Selangor as respondents from 106 people randomly selected to obtain quantitative data and 3 KKQ teachers as study participants to obtain qualitative data, which enriched the findings from the student study participants.

\section{RESULT AND DISCUSSION}

\section{Data analysis}

Quantitative data consisting of questionnaires were analyzed descriptively using the Statistical Package for the Social Sciences (SPSS) version 11.5 to obtain the frequency, percentage, mean and standard deviation. While the qualitative data obtained through semi-structured interviews on 3 participants of the teacher study were analyzed, transcribed verbatim and interpreted based on the elements in the evaluation of the teaching development component process. Before this study, all these instruments had gone through a process of validity and reliability to ensure that these instruments could measure and answer the research questions conducted. Thus, the validity and reliability of the questionnaire instrument have a high value with a correlation score between items exceeding 0.25 in addition to content validation by expert reference panel and the overall alpha value of 0.95 , indicating a high level of item reliability. In contrast, both questionnaire instrument and protocol semistructured interviews also went through a three -expert verification process. 
The researcher used the Mean Interpretation Table of Affective Behavior (Nunally 1978). This table has also been used by Farah Ilyani Zakaria in their study (Zakaria, 2011). The mean interpretation can be seen in Table 1 .

Table 1. Interpretation of Min Dimensions of Affective Behavior

\begin{tabular}{cc}
\hline Score min & Interpretation \\
\hline $4.01-5.00$ & High \\
\hline $3.01-4.00$ & High simple \\
\hline $2.01-3.00$ & Low simple \\
\hline $1.00-2.00$ & Low
\end{tabular}

In associating mean interpretation with the form of change that needs to be done as suggested by Stufflebeam, the classification of such form of change is homeostatic, incremental, neomobilistic and metamorphic (Stufflebeam 1971). Refer to Table 2.

Table 2. Combined Interpretation of Mean Nunally (1978) and Proposed Form of Stufflebeam Change (1971)

\begin{tabular}{cccl} 
Score min & Interpretation & Forms of change & \multicolumn{1}{c}{ Destination } \\
\hline $4.01-5.00$ & High & Homeostatic & $\begin{array}{l}\text { Maintain available balance in } \\
\text { the program }\end{array}$ \\
\hline $3.01-4.00$ & High simple & Incremental & $\begin{array}{l}\text { Development and Improvement } \\
\text { continues }\end{array}$ \\
\hline $2.01-3.00$ & Low simple & Neomobilistic & $\begin{array}{l}\text { Innovative venture and big } \\
\text { change }\end{array}$ \\
\hline $1.00-2.00$ & Low & Metamorphic & Change as a whole \\
\hline & Source: Azmil (2010)
\end{tabular}

Process evaluation findings in the teaching development component were analyzed based on student questionnaires and semi-structured teacher interviews.

\section{Problem Investigating Students About the Assessment of Teacher Teaching Development Components}

Table 3. Process Components: Teacher Teaching Development

\begin{tabular}{|c|c|c|c|c|c|c|c|c|c|}
\hline $\begin{array}{c}\text { Ite } \\
\mathrm{m}\end{array}$ & Statement & STS & $\mathrm{TS}$ & $\mathrm{KS}$ & S & SS & Min & S.P & $\begin{array}{l}\text { Interpretati } \\
\text { on }\end{array}$ \\
\hline 14 & $\begin{array}{l}\text { The teacher has extensive } \\
\text { knowledge about the } \\
\text { science of tarannum al- } \\
\text { Quran }\end{array}$ & $\begin{array}{c}0 \\
0 \%\end{array}$ & $\begin{array}{c}1 \\
1.3 \%\end{array}$ & $\begin{array}{c}7 \\
9 \%\end{array}$ & $\begin{array}{c}17 \\
21.8 \%\end{array}$ & $\begin{array}{c}53 \\
67.9 \%\end{array}$ & 4.56 & 0.71 & High \\
\hline 06 & $\begin{array}{l}\text { The teacher encouraged } \\
\text { me to master the recitation } \\
\text { of the Koran with } \\
\text { tarannum and recitation }\end{array}$ & $\begin{array}{c}0 \\
0 \%\end{array}$ & $\begin{array}{c}0 \\
0 \%\end{array}$ & $\begin{array}{c}10 \\
12.8 \%\end{array}$ & $\begin{array}{c}21 \\
26.9 \%\end{array}$ & $\begin{array}{c}47 \\
60.3 \%\end{array}$ & 4.47 & 0.72 & High \\
\hline 12 & $\begin{array}{l}\text { Teachers are not able to } \\
\text { control the classroom well } \\
\text { while teaching Tarannum } \\
\text { al-Quran }\end{array}$ & $\begin{array}{c}0 \\
0 \%\end{array}$ & $\begin{array}{c}4 \\
12 \%\end{array}$ & $\begin{array}{c}12 \\
15.4 \%\end{array}$ & $\begin{array}{c}17 \\
21.8 \%\end{array}$ & $\begin{array}{c}45 \\
57.7 \%\end{array}$ & 4.32 & 0.92 & High \\
\hline 05 & $\begin{array}{l}\text { My teacher showed me an } \\
\text { interesting example } \\
\text { reading at every time the } \\
\text { Tarannum al-Quran was } \\
\text { taught }\end{array}$ & $\begin{array}{c}1 \\
1.3 \%\end{array}$ & $\begin{array}{c}0 \\
0 \%\end{array}$ & $\begin{array}{c}11 \\
14.1 \%\end{array}$ & $\begin{array}{c}28 \\
35.9 \%\end{array}$ & $\begin{array}{c}38 \\
48.7 \%\end{array}$ & 4.31 & 0.81 & High \\
\hline 21 & $\begin{array}{l}\text { Teachers give praise to } \\
\text { students who can master } \\
\text { the recitation of the Qur'an } \\
\text { bertarannum }\end{array}$ & $\begin{array}{c}0 \\
0 \%\end{array}$ & $\begin{array}{c}2 \\
2.6 \%\end{array}$ & $\begin{array}{c}3 \\
3.8 \%\end{array}$ & $\begin{array}{c}42 \\
53.8 \%\end{array}$ & $\begin{array}{c}31 \\
39.7 \%\end{array}$ & 4.31 & 0.67 & High \\
\hline 17 & $\begin{array}{l}\text { The teacher asks each } \\
\text { student to repeat the } \\
\text { reading being taught }\end{array}$ & $\begin{array}{c}2 \\
2.6 \%\end{array}$ & $\begin{array}{c}2 \\
2.6 \%\end{array}$ & $\begin{array}{c}15 \\
19.2 \%\end{array}$ & $\begin{array}{c}22 \\
28.2 \%\end{array}$ & $\begin{array}{c}37 \\
41.4 \%\end{array}$ & 4.15 & 0.99 & High \\
\hline 02 & The teacher corrects the & 1 & 3 & 11 & 32 & 31 & 4.14 & 0.90 & High \\
\hline
\end{tabular}




\begin{tabular}{|c|c|c|c|c|c|c|c|c|c|}
\hline & $\begin{array}{l}\text { reading of each student } \\
\text { who has problems during } \\
\text { the lesson }\end{array}$ & $1.3 \%$ & $3.8 \%$ & $14.1 \%$ & $41 \%$ & $39.7 \%$ & & & \\
\hline 22 & $\begin{array}{l}\text { Teachers vary the } \\
\text { examples of melodies } \\
\text { while teaching the } \\
\text { recitation of Tarannum al- } \\
\text { Quran }\end{array}$ & $\begin{array}{c}0 \\
0 \%\end{array}$ & $\begin{array}{c}3 \\
3.8 \%\end{array}$ & $\begin{array}{c}14 \\
17.9 \%\end{array}$ & $\begin{array}{c}31 \\
39.7 \%\end{array}$ & $\begin{array}{c}30 \\
38.5 \%\end{array}$ & 4.13 & 0.84 & High \\
\hline 24 & $\begin{array}{l}\text { The teacher gave me the } \\
\text { opportunity to read } \\
\text { tantally in class }\end{array}$ & $\begin{array}{c}2 \\
2.6 \%\end{array}$ & $\begin{array}{c}5 \\
6.4 \%\end{array}$ & $\begin{array}{c}13 \\
16.7 \%\end{array}$ & $\begin{array}{c}19 \\
24.4 \%\end{array}$ & $\begin{array}{c}39 \\
50 \%\end{array}$ & 4.13 & 1.07 & High \\
\hline 09 & $\begin{array}{l}\text { Teachers are eager to } \\
\text { teach even to weak } \\
\text { students mastering the } \\
\text { Tarannum of the Quran }\end{array}$ & $\begin{array}{c}2 \\
2.6 \%\end{array}$ & $\begin{array}{c}6 \\
7.7 \%\end{array}$ & $\begin{array}{c}11 \\
14.1 \%\end{array}$ & $\begin{array}{c}30 \\
38.5 \%\end{array}$ & $\begin{array}{c}29 \\
37.2 \%\end{array}$ & 4.00 & 1.03 & $\begin{array}{l}\text { High } \\
\text { Simple }\end{array}$ \\
\hline 15 & $\begin{array}{l}\text { Teachers emphasize the } \\
\text { recitation of the Qur'an } \\
\text { bertarannum even } \\
\text { teaching the field of } \\
\text { memorization and qiraat }\end{array}$ & $\begin{array}{c}0 \\
0 \%\end{array}$ & $\begin{array}{c}5 \\
6.4 \%\end{array}$ & $\begin{array}{c}20 \\
25.6 \%\end{array}$ & $\begin{array}{c}25 \\
32.1 \%\end{array}$ & $\begin{array}{c}28 \\
35.9 \%\end{array}$ & 3.97 & 0.94 & $\begin{array}{l}\text { High } \\
\text { Simple }\end{array}$ \\
\hline 16 & $\begin{array}{l}\text { Teachers can deliver } \\
\text { interesting teaching }\end{array}$ & $\begin{array}{c}1 \\
1.3 \% \\
\end{array}$ & $\begin{array}{c}2 \\
2.6 \% \\
\end{array}$ & $\begin{array}{c}23 \\
29.5 \% \\
\end{array}$ & $\begin{array}{c}26 \\
33.3 \% \\
\end{array}$ & $\begin{array}{c}26 \\
33.3 \% \\
\end{array}$ & 3.95 & 0.92 & $\begin{array}{c}\text { High } \\
\text { Simple }\end{array}$ \\
\hline 10 & $\begin{array}{l}\text { The teacher delivered the } \\
\text { teachings of Tarannum al- } \\
\text { Quran. In an organized } \\
\text { and smooth manner }\end{array}$ & $\begin{array}{c}1 \\
1.3 \%\end{array}$ & $\begin{array}{c}5 \\
6.4 \%\end{array}$ & $\begin{array}{c}17 \\
21.8 \%\end{array}$ & $\begin{array}{c}30 \\
38.5 \%\end{array}$ & $\begin{array}{c}25 \\
32.1 \%\end{array}$ & 3.94 & 0.96 & $\begin{array}{l}\text { High } \\
\text { Simple }\end{array}$ \\
\hline 13 & $\begin{array}{l}\text { The teacher answers the } \\
\text { students 'questions in the } \\
\text { classroom clearly }\end{array}$ & $\begin{array}{c}1 \\
1.3 \%\end{array}$ & $\begin{array}{c}2 \\
2.6 \%\end{array}$ & $\begin{array}{c}21 \\
26.9 \%\end{array}$ & $\begin{array}{c}32 \\
41 \%\end{array}$ & $\begin{array}{c}22 \\
28.2 \%\end{array}$ & 3.92 & 0.88 & $\begin{array}{l}\text { High } \\
\text { Simple }\end{array}$ \\
\hline 20 & $\begin{array}{l}\text { The teacher divides the } \\
\text { students into small groups } \\
\text { for learning activities }\end{array}$ & $\begin{array}{c}2 \\
2.6 \%\end{array}$ & $\begin{array}{c}5 \\
6.4 \%\end{array}$ & $\begin{array}{c}25 \\
32.1 \%\end{array}$ & $\begin{array}{c}18 \\
23.1 \%\end{array}$ & $\begin{array}{c}28 \\
35.9 \%\end{array}$ & 3.83 & 1.07 & $\begin{array}{l}\text { High } \\
\text { Simple }\end{array}$ \\
\hline 04 & $\begin{array}{l}\text { The teacher's explanation } \\
\text { while teaching the } \\
\text { recitation of the Qur'an } \\
\text { bertarannum is easy for } \\
\text { me to understand }\end{array}$ & $\begin{array}{c}2 \\
2.6 \%\end{array}$ & $\begin{array}{c}9 \\
11.5 \%\end{array}$ & $\begin{array}{c}18 \\
23.1 \%\end{array}$ & $\begin{array}{c}29 \\
37.2 \%\end{array}$ & $\begin{array}{c}20 \\
25.6 \%\end{array}$ & 3.72 & 1.06 & $\begin{array}{l}\text { High } \\
\text { Simple }\end{array}$ \\
\hline 01 & $\begin{array}{l}\text { Teachers teach using a } \\
\text { variety of teaching } \\
\text { techniques and methods }\end{array}$ & $\begin{array}{c}1 \\
1.3 \%\end{array}$ & $\begin{array}{c}12 \\
15.4 \%\end{array}$ & $\begin{array}{c}17 \\
21.8 \%\end{array}$ & $\begin{array}{c}27 \\
34.6 \%\end{array}$ & $\begin{array}{c}21 \\
26.9 \%\end{array}$ & 3.71 & 1.07 & $\begin{array}{l}\text { High } \\
\text { Simple }\end{array}$ \\
\hline 11 & $\begin{array}{l}\text { Teachers pay attention to } \\
\text { each individual while } \\
\text { teaching }\end{array}$ & $\begin{array}{c}2 \\
2.6 \%\end{array}$ & $\begin{array}{c}8 \\
10.3 \%\end{array}$ & $\begin{array}{c}24 \\
30.8 \%\end{array}$ & $\begin{array}{c}26 \\
33.3 \%\end{array}$ & $\begin{array}{c}18 \\
23.1 \%\end{array}$ & 3.64 & 1.03 & $\begin{array}{l}\text { High } \\
\text { Simple }\end{array}$ \\
\hline 18 & $\begin{array}{l}\text { Teachers often ask } \\
\text { students who are good at } \\
\text { reading to listen to the } \\
\text { recitation of tarannum }\end{array}$ & $\begin{array}{c}3 \\
3.8 \%\end{array}$ & $\begin{array}{c}7 \\
9 \%\end{array}$ & $\begin{array}{c}23 \\
29.5 \%\end{array}$ & $\begin{array}{c}27 \\
34.6 \%\end{array}$ & $\begin{array}{c}18 \\
23.1 \%\end{array}$ & 3.64 & 1.06 & $\begin{array}{l}\text { High } \\
\text { Simple }\end{array}$ \\
\hline 23 & $\begin{array}{l}\text { Teachers can teach } \\
\text { Tarannum al-Quran even } \\
\text { if the allocation of } \\
\text { teaching time is limited }\end{array}$ & $\begin{array}{c}9 \\
11.5 \%\end{array}$ & $\begin{array}{c}9 \\
11.5 \%\end{array}$ & $\begin{array}{c}20 \\
25.6 \%\end{array}$ & $\begin{array}{c}22 \\
28.2 \%\end{array}$ & $\begin{array}{c}18 \\
23.1 \%\end{array}$ & 3.40 & 1.28 & $\begin{array}{l}\text { High } \\
\text { Simple }\end{array}$ \\
\hline 08 & $\begin{array}{lr}\text { Teacher } & \text { checked my } \\
\text { Tarannum } & \text { al-Quran } \\
\text { recitation } & \\
\end{array}$ & $\begin{array}{c}7 \\
9 \%\end{array}$ & $\begin{array}{c}12 \\
15.4 \%\end{array}$ & $\begin{array}{c}22 \\
28.2 \%\end{array}$ & $\begin{array}{c}18 \\
23.1 \%\end{array}$ & $\begin{array}{c}19 \\
24.4 \%\end{array}$ & 3.38 & 1.26 & $\begin{array}{l}\text { High } \\
\text { Simple }\end{array}$ \\
\hline 03 & 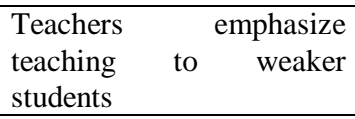 & $\begin{array}{c}6 \\
7.7 \%\end{array}$ & $\begin{array}{c}12 \\
15.4 \%\end{array}$ & $\begin{array}{c}25 \\
32.1 \%\end{array}$ & $\begin{array}{c}22 \\
28.2 \%\end{array}$ & $\begin{array}{c}13 \\
16.7 \%\end{array}$ & 3.31 & 1.15 & $\begin{array}{l}\text { High } \\
\text { Simple }\end{array}$ \\
\hline 07 & $\begin{array}{l}\text { The teacher involved my } \\
\text { friends who are better at } \\
\text { reciting bertarannum to } \\
\text { teach tarannum al-Quran } \\
\text { in groups }\end{array}$ & $\begin{array}{c}13 \\
16.7 \%\end{array}$ & $\begin{array}{c}8 \\
10.3 \%\end{array}$ & $\begin{array}{c}30 \\
38.5 \%\end{array}$ & $\begin{array}{c}18 \\
23.1 \%\end{array}$ & $\begin{array}{c}9 \\
11.5 \%\end{array}$ & 3.03 & 1.22 & $\begin{array}{l}\text { High } \\
\text { Simple }\end{array}$ \\
\hline 19 & $\begin{array}{l}\text { Teachers } \\
\text { opportunities for students } \\
\text { to be active during P\&P }\end{array}$ & $\begin{array}{c}20 \\
25.6 \%\end{array}$ & $\begin{array}{c}23 \\
29.5 \%\end{array}$ & $\begin{array}{c}19 \\
24.4 \%\end{array}$ & $\begin{array}{c}14 \\
17.9 \%\end{array}$ & $\begin{array}{c}2 \\
2.6 \%\end{array}$ & 2.42 & 1.13 & $\begin{array}{l}\text { High } \\
\text { Simple }\end{array}$ \\
\hline
\end{tabular}




\section{Min overall}

$3.85 \quad 0.55$

High

*Negative items that were pre-coded

STS $=$ Strongly Disagree TS $=$ Disagree KS $=$ Disagree $S=$ Agree SS $=$ Strongly Agree

Table 3 above displays the items regarding the components of teacher teaching development according to students' perceptions are at a high level. The items are the item 'teachers have extensive knowledge of the science of tarannum al-Quran' with $67.9 \%$ stating strongly agree (mean $4.56, \mathrm{sp}=0.71$ ), the item 'teachers encourage me to master the recitation of al-Quran bertarannum along with tajwid' with $60.3 \%$ stating strongly agree $($ mean $=4.47, \mathrm{sp}=0.72)$, item 'teachers cannot control the classroom well while teaching Tarannum al-Quran' with $57.7 \%$ stating strongly agree (mean = $4.32, \mathrm{sp}=0.92$ ), item 'teachers show interesting example recitation in each teaching of Tarannum al-Quran' with $48.7 \%$ stating strongly agree (mean $=4.31, \mathrm{sp}=0.81$ ), item 'teachers give praise to students who can master the recitation of al-Quran bertarannum' with $39.7 \%$ expressed strongly agree $($ mean $=4.31$, sp $=0.67)$, item 'teacher asks each student to repeat the reading taught' with $41.4 \%$ described strongly agree $($ mean $=4.15, \mathrm{sp}=0.99)$, item 'teacher corrects each student's reading problematic during teaching 'with $39.7 \%$ menyat will strongly agree (mean $=4.14$, sp $=0.90$ ), the item 'teachers diversify examples of melody while teaching the recitation of Tarannum al-Quran' with $38.5 \%$ stating strongly agree (mean $=4.13, \mathrm{sp}=0.84$ ) and the item 'teachers give opportunities to students to read bertarannum in class' with $50 \%$ expressing strongly agree $($ mean $=4.13, \mathrm{sp}=1.07)$.

While 14 items submitted were at a medium to high level. These items are the item 'teachers are eager to teach even to students who are weak in mastering the Tarannum al-Quran' with $37.2 \%$ stating strongly agree (mean $=4.00, \mathrm{sp}=1.03$ ), the item 'teachers emphasize the recitation of the Quran bertarannum even teaching memorization and qiraat 'with $35.9 \%$ expressed strongly agree $($ mean $=3.97, \mathrm{sp}=$ 0.94), item' teachers can deliver interesting lessons 'with $33.3 \%$ expressed strongly agree (mean $=3.95, \mathrm{sp}=0.92$ ), item' teachers deliver Tarannum teaching al-Quran in an organized and fluent manner 'with $32.1 \%$ stating strongly agree (mean $=3.94$, $\mathrm{sp}=$ 0.96), the item' teachers answer students 'questions in the classroom clearly' with $28.2 \%$ stating strongly agree $($ mean $=3.92, \mathrm{sp}=0.88)$, item 'teachers divide students into small groups for learning activities' with $35.9 \%$ stating strongly agree (mean $=$ 3.83 , sp = 1.07), item 'teacher's description while teaching recitation of the Qur'an bertarannum easy to understand by students' with $25.6 \%$ stating strongly agree ( $\mathrm{min}=$ 3.72 , $\mathrm{sp}=1.06$ ), the item 'teachers teach using various teaching techniques and methods' with $26.9 \%$ strongly agree (mean $=3.71, \mathrm{sp}=1.07$ ), the item 'teachers pay attention to each individual while teaching' with $23.1 \%$ strongly agree (mean $=3.64$, $\mathrm{sp}=1.03$ ), the item 'teachers often tell good students to read tarannum' with $23.1 \%$ expressing strongly agree (mean $=3.64, \mathrm{~s}, \mathrm{p}=1.06$ ), the item 'teachers can teach Tarannum al- Quran although the allocation of teaching time is limited 'with $23.1 \%$ expressing strongly agree (mean $=3.40, \mathrm{sp}=1.28$ ), the item' teachers check the reading of Tarannum al-Quran students' with $24.4 \%$ expressing strongly agree (mean $=3.38, \mathrm{sp}=1.26$ ), the item 'teachers emphasize teaching to weak students' with $16.7 \%$ stating strongly agree (mean $=3.31, \mathrm{sp}=1.15)$ and the item 'teachers involve better friends reciting bertarannum to teach tarannum al-Quran in groups' with $11.5 \%$ expressed strongly agree $($ mean $=3.03, \mathrm{sp}=1.22$ ).

While only one item at the medium-low level that is 'teachers allow students to be active during $\mathrm{P} \& \mathrm{P}^{\prime}$ with a mean value of 2.42 and a standard deviation of 1.13 with 
2.6\% expressed strongly agree. In conclusion, the overall mean for evaluating the components of teacher teaching development on students' perceptions was at a moderately high level with a mean value of 3.85 and a standard deviation of 0.55.

\section{Semi-Structured Teacher Interviews on the Assessment of Teacher Teaching Development Components}

\begin{tabular}{ll} 
& $\begin{array}{c}\text { Example 1: Interview Data (T1) on teacher techniques } \\
\text { in the teacher teaching development component (Source: G1). }\end{array}$ \\
Researchers & $: \quad$ What is the most dominant technique that ustaz uses in teaching Tarannum? \\
\hline Teacher 1 & $: \quad \begin{array}{l}\text { In teaching Tarannum, I most often use the method of qit'ah after qit'ah or students } \\
\text { master one harakah through pieces of harakah }\end{array}$
\end{tabular}

\begin{tabular}{lll}
\hline Researchers & $: \begin{array}{l}\text { Is it easy for students to master the harakah-harakah of the song through this } \\
\text { method? }\end{array}$ \\
\hline Teacher 1 & $: \begin{array}{l}\text { We make these pieces to make it easier for students to master the melody of one } \\
\text { harakah that is learned. Because each of the pieces has its ups and downs and the } \\
\text { arrangements of the burdah are specific and different. So if we read the harakah } \\
\text { one by one directly, this will make it difficult for students }\end{array}$
\end{tabular}

\begin{tabular}{lll}
\hline Researchers & $:$ & What are the next steps? \\
\hline Teacher 1 & $:$ & I will ask the students to draw on the pieces of the harakah how the shape of the \\
& graphic that they themselves understand whether the rhythm goes up or down
\end{tabular}

\begin{tabular}{|c|c|c|}
\hline Researchers & : & Meaning, they will sketch according to their own understanding? \\
\hline Teacher 1 & : & $\begin{array}{l}\text { Yes, this self -sketching method makes it easy for them to understand and } \\
\text { remember. They will repeat each qit'ah until they can until one harakah is over. If } \\
\text { the mahattah runs away from the real melody, it means that there are qit'ahs that } \\
\text { have not been mastered by the student }\end{array}$ \\
\hline
\end{tabular}

Based on the interview data (T1) above, the researcher found that Tarannum al-Quran KKQ teachers teach using various teaching techniques and methods. Among the ways that teachers often use is to learn tarannum in qit'ah after qit'ah to ensure that students can master the harakah-harakah of tarannum that are known well. Through this method, teachers can detect qit'ahs that are a real problem to the mastery of students, such as failure to master salalim nuzul (descending stairs) or salalim su'ud (ascending stairs) or the inability to wave burdah (flowers -song flowers) correctly. Thus, the technique of repeating qit'ah or harakah is a technique that is often used by teachers in the teaching and learning of Tarannum to help students master the tarannum of the Quran.

Example 2: Teacher Interview Data (T2) Explaining

the Importance of Repetition (Takrir) Methods in Teaching Development Components (Source: G2).

Researchers : How many times do students need to repeat the strains each day?

Teacher 2 : Until you get. While it can't be re-hit again from the beginning of the day

Researchers : Is it important not for students to continue to be able to present the strains during the class?

Teacher 2 : Of course, that's why Tarannum's teaching time can't teach much. Sometimes sometimes in one P\&P can only teach three harakah songs. The rest have to be connected again. We want students to be able to sing tarannum before leaving class

\begin{tabular}{lll}
\hline Researchers $:$ & What if you forget? \\
\hline Teacher 2 & $:$ & Thats normal. Want to remember one harakah melody, students have to practice a \\
& $\begin{array}{l}\text { lot on their own to become proficient. If it's good, we try different strains in } \\
\text { different }\end{array}$
\end{tabular}


Researchers : If you want to be able to share and remember one of the tunes, what is it like?

Teacher 2 : At this school, students sit in dormitories. They have a lot of practice together at the hostel. Sometimes even more senior students teach their siblings a lot. That's why I use the same surah approach a lot for all levels. Arguably they will refer to the model surahs we teach when learning tarannum

Based on the interview (T2) above, the researcher found that KKQ teachers often practice the method of takrir or repeating qit'ah or harakah. The role of better students in the classroom is also highlighted as a stimulus of other friends in learning tarannum either in the classroom or dormitory. Researchers found that teachers using the role of peers as continuous mentors can avoid allocating time for Tarannum P\&P at the school. The teachers interviewed used the same surahs to master one tarannum to be learned by KKQ students at all levels. This will make it easier for KKQ students to learn the tarannum syllabus when reading the surahs that have been set for each group. KKQ teachers also rely on surahs that are considered model surahs so that students are not confused in mastering the harakahs of tarannum.

Example 3: Interview Data (T3) on the relevance of bertarannum teachers' abilities in teaching development (Source: G3).

Researchers : Does the ustaz diversify the melody of tarannum in teaching?

Teacher 3 : That must be because there are many verses in the Qur'an. Some are long, some are short. Some are waqf with mad aridh lissukun and some are waqf with mad iwadh

\begin{tabular}{lll}
\hline Researchers & Students do not feel dizzy with lots of examples? \\
\hline Teacher 3 & $:$ At first it was dizzy but after a long time it became normal. Only then do they \\
& understand how to apply it in the various verses of the Qur'an. However, they only \\
& adhere to the verses or surahs that are in the syllabus
\end{tabular}

Researchers : Does the ustaz agree that the tarannum of the Quran can also be applied in the teaching of tajwid and qiraat?

Teacher 3 : Yes, I agree but this is really necessary for teachers who are proficient in tarannum

\begin{tabular}{lll}
\hline Researchers & $:$ & How is the application of tarannum made in the teaching of tajwid and qiraat? \\
\hline Teacher 3 & $: \begin{array}{l}\text { Because the teaching of tajwid and qiraat is also the recitation of the Quran. After } \\
\text { all Tarannum can be applied in the recitation of tartil, tadwir or hadar. That's why } \\
\text { I say it depends on the skills of the teacher who teaches }\end{array}$
\end{tabular}

The interview (T3) above shows that the KKQ Tarannum teachers have high skills by the KKQ Tarannum al-Quran syllabus, which requires the skills and expertise of the teachers. This high ability of teachers allows tarannum to be applied in other KKQ subjects such as tajwid, memorization and qiraat. Teachers' skills were also acknowledged by students in the findings of the questionnaire. Thus this interview shows that these teacher skills enable teachers to diversify reading examples throughout the Tarannum P\&P. Bertarannum readings can be applied in different and varied sentence patterns. This interview also shows that the variety of bertarannum readings by teachers is significant throughout the development process of $\mathrm{P} \& \mathrm{P}$ to ensure that students understand the application of one harakah in different verses of the Qur'an in length and short.

\section{Discussion}

Based on the study's findings, Tarannum al-Quran teachers adopt various teaching strategies and techniques to achieve teaching objectives (Husin, 1987). They are not limited and stereotyped to a single teaching method to ensure a more effective 
teaching development process (Woolfolk, 2002). This is important to maintain students 'interest in teacher descriptions (Sang, 2009).

The sequence of the use of various techniques and strategies by teachers in the teaching and learning of Tarannum al-Quran also shows that teachers also consider the diversity of levels and abilities of students. This finding coincides with the recommendation of Mueller and Mueller (Mueller and Mueller, 1992), who stated that teachers who use limited teaching strategies would limit the potential of their abilities, which closes the space to all students. These findings also coincide with Ruslin Amir (Amir, 2007). Ibn Khaldun also once pointed out that if a teacher's teaching is not balanced with the student's abilities, perhaps the learning objectives will not be achieved (Khaldun, 2000). Moreover, the analysis of the findings of this study shows that teachers' ability in the field of tarannum al-Quran on students' perception is at a high level based on the highest mean on the item "teachers have extensive knowledge of tarannum al-Quran". This allows teachers to diversify examples of tarannum tunes to attract students 'interest in accordance with the diversity of students' levels and abilities.

The findings of this study also found that Tarannum al-Quran KKQ teachers use various appropriate techniques (Ariffin, 1998). In addition to positive reinforcement was found to always occur in teacher-student interaction (Abdullah, 2000). This situation is in line with Ellis (Ellis, 1995), who stated that the teaching approach should create frequent positive interactions among students. Researchers also found that teachers practice teaching following little by little to strengthen the student experience. This strategy is very suitable as the objective of Tarannum al-Quran P\&P is in the form of mastery of skills, not just theory. This is in line with the recommendations of Kamarudin (Husin, 1987) and Ibnu Khaldun (Khaldun, 2000), who also emphasize the appropriateness of the steps of teaching content gradually and gradually following the level of intellectual ability of students, whether excellent, average or weak. Thus, strategies of using various stimuli through ABM, examples, and so on were found to have been used to achieve the success of the optimal teaching development process. This is in line with Mok Soon Sang (Sang, 2009). He has outlined four components that must be present in the illuminating skills in the teaching development process, namely the beginning level, illustration skills, organizing ideas and closing.

Through this study, researchers found that teachers of tarannum al-Quran have applied various methods suitable for teaching tarannum al-Quran such as talaqqi musyafahah, graph method, takrir method (repetition), habituation method, demonstration method, practice and drill, taushih and tatbiqi methods. Appropriate methods used in the education of Quranic skills are also presented by the study of Mohd Napiah Sahrani (Sahrani, 1998), Zulkifli bin Dahlan (Dahlan, 1999), Muhammad Zawawi Muhammad Ali@ Yusof (Yusof, 2004a), Karim (Karim 2008), Ahmad Sahli Hasan (Hasan, 2008), Saidah Harith (Harith, 2009).

Process evaluation has very important implications for the implementation of teacher M\&M practices. The research findings found that gradual changes need to be made in the components of teaching development. Based on the Combination of Mean Nunally's Interpretation (1978) and Stufflebeam's (1971) Change Proposal Form, this change requires continuous development and improvement in the implementation of 
developmental components by perfecting the design of instructional procedures and structuring P\&P activities to make them better and in line with teaching objectives.

\section{CONCLUSION}

In conclusion, although the research findings show that KKQ Tarannum al-Quran teachers understand and practice the elements of teaching development that must be present in the P\&P process, but only at a high enough level. Overall, KKQ tarannum teachers have successfully implemented various strategies and appropriate learning steps in the learning development component. However, it can still be improved through optimal efforts from teachers. Teachers' skills in mastering the development process can still be improved for the better.

\section{REFERENCES}

[1] Abdullah, M. K. (2000) Pengajaran Sejarah: persediaan guru, matlamat pengajaran dan sikap guru. Universiti Sains Malaysia.

[2] Al-Kailany, T. and Iyad, M. (1986) Al-Taujih al-fanny fi usul al-tarbiyah wa altadris. Beirut: Maktabah Lubnan.

[3] Al-Syaibani, O. M. al-T. (1978) Falsafah Pendidikan Islam. Jakarta: Bulan Bintang.

[4] Amir, R. (2007) Hubungan stail pengajaran, stail berfikir dan stail pembelajaran dalam kalangan murid UKM. Fakulti Pendidikan. Bangi: UKM.

[5] Ariffin, S. R. (1998) Kajian mengenai sikap terhadap sains dan pencapaian dalam mata pelajaran Sains Paduan bagi murid tingkatan tiga. Fakulti Pendidikan. Bangi: UKM.

[6] Armstrong, D. G., T.Henson, K. and Savage, T. V. (2001) Teaching Today- An Introduction To Education. Merrill Prentice-Hall, Inc.

[7] Brophy, J. E. and Good, T. L. (1986) Teacher behavior and student achievement. Dlm. Witrock, M.C. (pnyt) Hand Book Of Research Of Teaching: A Project Of The American Educational Research Association. New York: McMillan Publishing Company.

[8] Dahlan, Z. bin (1999) Metodologi tarannum MPI. Kajian keberkesanan, kekuatan dan Kelemahan: Satu Penilaian Semula. UKM.

[9] Daughtery, A. S. and Ristau, R. A. (1991) Basic Business And Economic Education, Learning And Instruction. Ohio: South Western Publishing Company.

[10] Din, A. G. M. (2003) Prinsip Dan Amalan Pengajaran. Kuala Lumpur: Utusan Publiations \& Distributors Sdn. Bhd.

[11]Ellis, A. K. (1995) 'Teaching and learning multiple perspectives: The atomic bomb', The Social Studies, 91(4), pp. 1-7.

[12] Faujdar, M. S. (2000) Kualiti pengajaran Sejarah di sebuah sekolah menengah daerah Sabak Bernam. Universiti Malaya.

[13] Green, J. \& Mc Lintock, C. (1985) 'Triangulation in evaluation: Design and analysis issues', Evaluation Review, 9(5), pp. 523-545. 
[14] Harith, S. H. @ (2009) Musicology in Islam and quranic chanting. Program Pascasarjana Institut Agama Islam Negeri Syarif Hidayatullah Jakarta.

[15] Hasan, A. S. M. (2008) Kelas Kemahiran Al-Quran (KKQ) di SMKA Falahiah Pasir Pekan: Tinjauan mengenai metodologi pengajaran dan keberkesanannaya. Akademi Pengajian Islam. Kuala Lumpur: Universiti Malaya.

[16] Husin, K. (1987) Panduan Latihan Mengajar. Longman: Petaling Jaya.

[17] Ikhwan, A. et al. (2021) 'Tahsin and Tahfidz Learning System at Integrated Islamic Elementary School ( SDIT ) Insan Madani During the Pandemic Covid-19', AlHayat: Journal of Islamic Education (AJIE), 5(1), pp. 1-11.

[18] Jaid, M. Z. A. bin M. (2008) Pembangunan dan Penilaian Laman Web "Kelas Kemahiran al-Quran. Fakulti Pendidikan Universiti Kebangsaan Malaysia.

[19] Jamil, H. (2003) Teknik Mengajar Sejarah. Kuala Lumpur: PTS Publications \& Distributors Sdn. Bhd.

[20] Jemali, M. (2006) 'Tahap Pencapaian penguasaan al-Quran dalam kalangan pelajar di Perak', in Kajian cuti sabatikal: UPSI.

[21] Khaldun, I. (2000) Muqaddimah Ibn Khaldun. Terj. Kuala Lumpur: Dewan Bahasa dan Pustaka.

[22] Mat, E. (2010) Kelas Khas Kemahiran al-Qur'an (KKQ): Kajian kaedah pelaksanaan dan keberkesanannya di sekolah-sekolah menengah (SMK) di daerah Gombak, Selangor. Akademi Pengajian Islam. Kuala Lumpur: Universiti Malaya.

[23] Mueller, R. and Mueller, S. (1992) 'The spectrum of teaching styles and its role in conscious deliberate teaching', Journal Of Physical Education, Recreation(63), pp. $48-53$.

[24] Myers, C. B. and Myers, L. . (1995) The Professional Educator: A New Introduction To Teaching And School. Belmont: Wadsworth Publishing Company.

[25] Neuman, W. L. (2000) Social Research Methods: Qualitative And Quantitative Approaches. Needham Heights: Allyn \& Bacon.

[26] Noh, M. A. C. and Tarmizi, R. A. (2009) 'Persepsi pelajar terhadap amalan pengajaran Tilawah al-Quran', Jurnal Pendidikan Malaysia UKM, 34(1), pp. 93109.

[27] Noordin, T. A. and Dan, N. A. (2002) 'Kurikulum Pendidikan Islam: Penjelasan menurut paradigm pendidikan bersepadu', in Prosiding Wacana Pendidikan Islam (Siri 1). Malaysia: Fakulti Pendidikan Universiti Kebangsaan Malaysia.

[28] Purwanto, N. (1990) Psikologi pendidikan. Bandung: Rosdakarya.

[29] Razali, S. N. (2001) Pedagogi Teori Dan Praktik. Kuala Lumpur: Dewan Bahasa dan Pustaka.

[30] Sahrani, M. N. (1998) Tarannum al-Quran: Metode pelaksanaannya dalam kurikulum Kelas Khas Kemahiran al-Quran di sekolah-sekolah menengah kebangsaan agama di Malaysia. Program Pascasarjana. Institut Agama Islam Negeri Syarif Hidayatullah. Jakarta.

[31] Sang, M. S. (2009) Teks Komprehensif PTK (Penilaian Tahap Kecekapan) Bahagian II: Khusus / Fungsional P\&P. Selangor: Penerbitan Multimedia Sdn. 
Bhd.

[32] Stufflebeam, D. L. and Shinkfield, A. . (1985) Systematic Evaluation: A Self Guide To Theory And Practice. Boston: Kluwer-Nijhoff Publishing.

[33] Woolfolk, A. E. (2002) Educational Psychology. 4th Edition. New Jersey: Prentice Hall, Inc.

[34] Yusof, M. Z. M. A. @ (2004a) Perlaksanaan Pendidikan Kelas Khas Kemahiran al-Quran (KKQ) di Sekolah-Sekolah Menengah Kebangsaan Agama Negeri Johor. Satu kajian. Fakulti Pendidikan Universiti Teknologi Mara.

[35] Yusof, M. Z. M. A. @ (2004b) Perlaksanaan Pendidikan Kelas Khas Kemahiran al-Quran (KKQ) di Sekolah-Sekolah Menengah Kebangsaan Agama Negeri Johor. Fakulti Pendidikan Universiti Teknologi Mara.

[36]Zakaria, F. I. (2011) Penilaian Pelaksanaan Pengajaran dan Pembelajaran Tarannum al-Quran Kelas Khas Kemahiran Membaca dan Menghafaz al-Quran $(K K Q)$ di Selangor. Fakulti Pendidikan. Bangi: Universiti Kebangsaan Malaysia. 